Article

\title{
Polyoxygenated Sterols from the South China Sea Soft Coral Sinularia sp.
}

\author{
Rui Li ${ }^{1}$, Chang-Lun Shao ${ }^{1}$, Xin Qi ${ }^{1}$, Xiu-Bao Li ${ }^{2}$, Jing $\mathrm{Li}^{1}$, Ling-Ling Sun ${ }^{1}$ and \\ Chang-Yun Wang ${ }^{1, *}$
}

1 Key Laboratory of Marine Drugs, Ministry of Education of China, School of Medicine and Pharmacy, Ocean University of China, Qingdao 266003, China;

E-Mails: lirui30502@163.com (R.L.); shaochanglun@163.com (C.-L.S.); qxhin@163.com (X.Q.); 1jlilac@163.com (J.L.); sunllqd@163.com (L.-L.S.)

2 South China Sea Institute of Oceanology, Chinese Academy of Sciences, Guangzhou 510000, China; E-Mail: lixiubao@scsio.ac.cn

* Author to whom correspondence should be addressed; E-Mail: changyun@ouc.edu.cn; Tel./Fax: +86-0532-82031536.

Received: 28 March 2012; in revised form: 29 May 2012 / Accepted: 8 June 2012 /

Published: 26 June 2012

\begin{abstract}
Chemical investigation of the ethanol extract of soft coral Sinularia sp. collected from the South China Sea led to the isolation of three new polyoxygenated sterols, (3S,23R,24S)-ergost-5-ene-3 $\beta, 23 \alpha, 25$-triol (1), (24S)-ergostane-6-acetate-3 $\beta, 5 \alpha, 6 \beta, 25$-tetraol (2), (24S)-ergostane-6-acetate-3 $\beta, 6 \beta, 12 \beta, 25$-tetraol (3) together with three known ones (4-6). The structures, including relative configurations of the new compounds (1-3), were elucidated by detailed analysis of spectroscopic data (IR, UV, NMR, MS) and by comparison with related reported compounds. The absolute configuration of $\mathbf{1}$ was further determined by modified Mosher's method. Compound $\mathbf{5}$ exhibited moderate cytotoxicity against $\mathrm{K} 562$ cell line with an $\mathrm{IC}_{50}$ value of $3.18 \mu \mathrm{M}$, but also displayed strong lethality toward the brine shrimp Artemia salina with a $\mathrm{LC}_{50}$ value of $0.96 \mu \mathrm{M}$.
\end{abstract}

Keywords: soft coral; Sinularia sp.; polyoxygenated sterols; cytotoxicity

\section{Introduction}

Soft coral of the genus Sinularia has been found to be a rich source of bioactive secondary metabolites [1,2], such as acylated spermidine [3,4], lipids and fatty acids [5], cyclic sesquiterpene 
peroxides [6], sterols [7,8], and norditerpenes [9,10]. A number of them showed an array of biological activities such as cytotoxic activities $[3,4]$ and inhibitory effect on LPS-induced TNF- $\alpha$ production $[9,10]$. As part of our ongoing investigation of new natural bioactive compounds from marine invertebrates in the South China Sea [11-16], the soft coral Sinularia sp. attracted our attention because the crude extract of Sinularia sp. showed lethal activity toward brine shrimp Artemia salina. Bioassay-guided fractionation of the active extracts led to the isolation of three new polyoxygenated sterols (1-3) and three known ones (4-6) [17,18] (Figure 1).

Figure 1. Structures of compounds 1-6 from Sinularia sp.

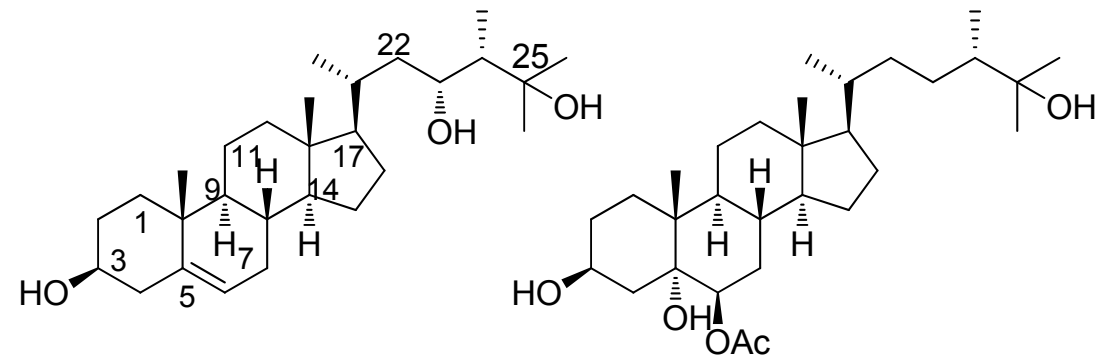

1

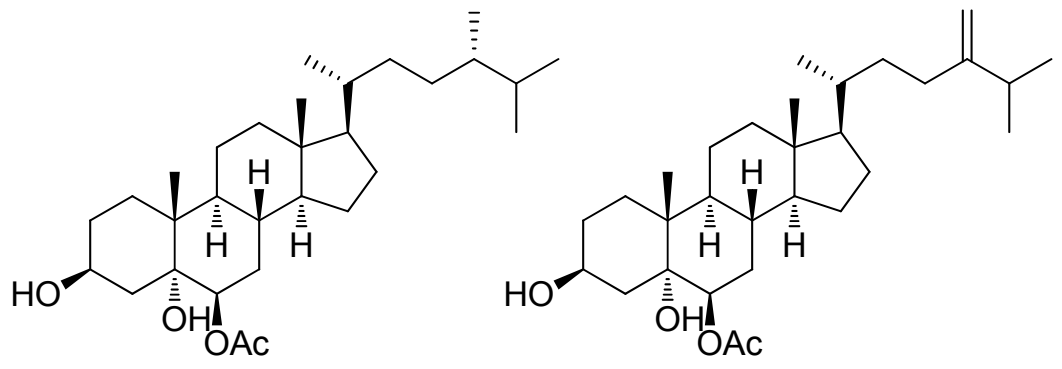

4<smiles>CC[C@H](C)O[C@H](C)O[C@H](C)CC[C@H](C)C(C)(C)O</smiles>

7

5

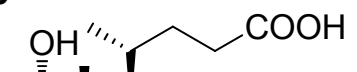

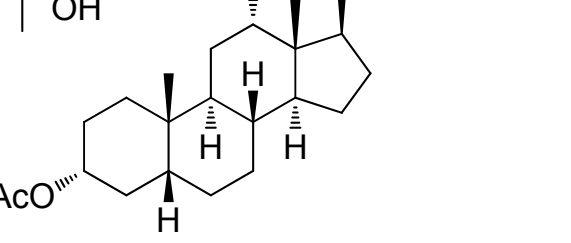

8

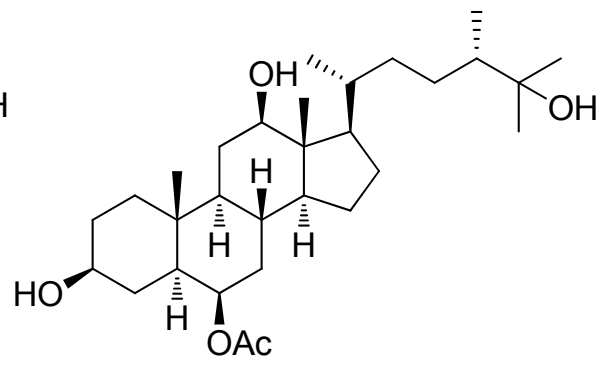

3

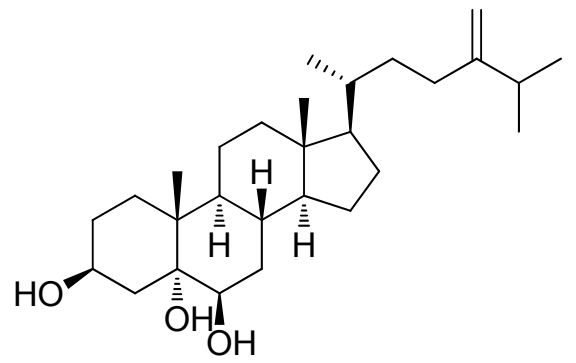

6

\section{Results and Discussion}

Compound 1 was obtained as a white, amorphous powder with $[\alpha]_{\mathrm{D}}^{25}-22.4\left(c 0.05, \mathrm{CH}_{3} \mathrm{OH}\right)$. IR spectrum showed its absorption at $3410-3584 \mathrm{~cm}^{-1}$ for hydroxy groups. The molecular formula was established as $\mathrm{C}_{28} \mathrm{H}_{48} \mathrm{O}_{3}$ based on HRESIMS ([M $\left.+\mathrm{Na}\right]^{+} 455.3498$ (calcd for $\left.\mathrm{C}_{28} \mathrm{H}_{48} \mathrm{O}_{3} \mathrm{Na} 455.3496\right)$ ) and NMR spectroscopic data. The ${ }^{1} \mathrm{H}-\mathrm{NMR}$ (Table 1) and ${ }^{13} \mathrm{C}-\mathrm{NMR}$ (Table 2) spectra implied that compound 1 was a polyhydroxylated sterol. The ${ }^{1} \mathrm{H}-\mathrm{NMR}$ spectrum of $\mathbf{1}$ revealed four methyl singlet signals at $\delta_{\mathrm{H}} 0.70\left(3 \mathrm{H}, \mathrm{s}, \mathrm{H}_{3}-18\right), 1.00\left(3 \mathrm{H}, \mathrm{s}, \mathrm{H}_{3}-19\right), 1.23\left(3 \mathrm{H}, \mathrm{s}, \mathrm{H}_{3}-26\right)$ and $1.23\left(3 \mathrm{H}, \mathrm{s}, \mathrm{H}_{3}-27\right)$, and two methyl doublet signals at $\delta_{\mathrm{H}} 0.81\left(3 \mathrm{H}, \mathrm{d}, J=6.6 \mathrm{~Hz}, \mathrm{H}_{3}-28\right)$ and $1.08\left(3 \mathrm{H}, \mathrm{d}, J=6.6 \mathrm{~Hz}, \mathrm{H}_{3}-21\right)$, as well as two oxymethines $\left(\delta_{\mathrm{H}} 3.71\right.$ and 3.56), and an olefinic proton signal at $\delta_{\mathrm{H}} 5.34$ (br d, $J=4.8 \mathrm{~Hz}$ ). The ${ }^{13} \mathrm{C}$-NMR and DEPT spectra of 1 displayed 28 signals which were assigned to four 
quaternary carbons, nine methines, nine methylenes, and six methyls. The olefinic carbon signals appearing at $\delta_{\mathrm{C}} 140.8(\mathrm{C})$ and $121.6(\mathrm{CH})$ corresponded to one trisubstituted double bond. The ${ }^{13} \mathrm{C}$-NMR chemical shifts at $\delta_{\mathrm{C}} 75.8(\mathrm{CH}), 75.2(\mathrm{C})$ and $71.8(\mathrm{CH})$ confirmed the presence of three oxygenated carbons. Detailed analysis of the ${ }^{1} \mathrm{H}-{ }^{1} \mathrm{H}$ COSY spectrum in combination with HMQC and HMBC (Figure 2) experiments allowed the assignment of all of the chemical shifts in the ${ }^{1} \mathrm{H}$ and ${ }^{13} \mathrm{C}-\mathrm{NMR}$ spectra and led to structure 1. Comparison of ${ }^{1} \mathrm{H}-\mathrm{NMR}$ and ${ }^{13} \mathrm{C}$-NMR of $\mathbf{1}$ with those of the known compound 7 (patusterol A) [19], a hydroxylated steroid from the Kenyan soft coral Lobophytum patulum, further confirmed the structure of $\mathbf{1}$. The obvious differences between the two compounds are the chemical shifts at $\delta_{\mathrm{H}} 3.71(1 \mathrm{H}$, ddd, $J=12.0,8.4,3.0 \mathrm{~Hz}, \mathrm{H}-23)$ in 1 vs. $3.71(1 \mathrm{H}$, br t, $J=2.6 \mathrm{~Hz}, \mathrm{H}-1)$ in 7, and $\delta_{\mathrm{C}} 75.8(\mathrm{CH})$ in 1 vs. $72.5(\mathrm{CH})$ in 7, indicating that the hydroxyl group in $\mathbf{1}$ is at $\mathrm{C}-23$ not as 7 at $\mathrm{C}-1$. In addition, the ${ }^{1} \mathrm{H}-{ }^{1} \mathrm{H}$ COSY correlations of $\mathrm{H}-23$ with $\mathrm{H}-24$ and $\mathrm{H}-22$, and the HMBC correlations from $\mathrm{H}_{3}-28$ to $\mathrm{C}-24, \mathrm{C}-23$ and $\mathrm{C}-25$ enable the hydroxyl group to be placed at C-23. The relative stereochemistry of $\mathbf{1}$ was assigned on the basis of 2D NOESY experiment. In the NOE spectrum of 1 , NOE correlations observed from $\mathrm{H}_{3}-18$ to $\mathrm{H}-20$ indicated that $\mathrm{H}-20$ was in $\beta$ disposition. The $\alpha$ orientation of $\mathrm{H}-9$ and $\mathrm{H}-14$, and $\beta$ orientation of $\mathrm{H}-8$ were also determined by NOESY experiment. The absolute configuration at C-3 and C-23 of 1 was tried to determine using the modified Mosher's method [20]. The $(S)$ - and $(R)$-MTPA esters 1r and 1s were prepared using $(R)$ - and $(S)$-MTPA chloride, respectively. The determination of $\Delta \delta$ values $\left(\delta_{S}-\delta_{R}\right)$ (Figure 3) for protons neighboring $\mathrm{C}-3$ and $\mathrm{C}-23$ should lead to the assignment of the configuration at C-3 and C-23 in 1. The configuration at $\mathrm{C}-24$ in this and congener sterols was suggested as $24 S$ on biogenetic grounds, since almost all the 24-methylsterols isolated from corals have $24 S$ stereochemistry according to the literature $[21,22]$. According to the relatively small difference of $\Delta \delta$ values $\left(\delta_{S}-\delta_{R}\right)$, the absolute configuration of 1 was tentatively determined as $(3 S, 23 R, 24 S)$-ergost-5-ene-3 $\beta, 23 \alpha, 25$-triol.

Table 1. ${ }^{1} \mathrm{H}-\mathrm{NMR}$ data for compounds $\mathbf{1}-\mathbf{3}$.

\begin{tabular}{|c|c|c|c|}
\hline $\mathbf{H \#}$ & $1, \delta_{\mathrm{H}}(J \text { in Hz})^{a}$ & $2, \delta_{\mathrm{H}}(J \text { in } \mathrm{Hz})^{b}$ & $3, \delta_{\mathrm{H}}(J \text { in } \mathrm{Hz})^{a}$ \\
\hline \multirow[t]{2}{*}{1} & $1.82(1 \mathrm{H}, \mathrm{d}, J=4.8 \mathrm{~Hz}, \mathrm{H}-\mathrm{ax})$ & $1.75(1 \mathrm{H}$, br d, $J=12.0 \mathrm{~Hz}, \mathrm{H}-\mathrm{ax})$ & $1.82(1 \mathrm{H}, \mathrm{br} \mathrm{d}, J=4.8 \mathrm{~Hz}, \mathrm{H}-\mathrm{ax})$ \\
\hline & $1.12(1 \mathrm{H}, \mathrm{m}, \mathrm{H}-\mathrm{eq})$ & $1.18(1 \mathrm{H}, \mathrm{m}, \mathrm{H}-\mathrm{eq})$ & $1.27(1 \mathrm{H}, \mathrm{m}, \mathrm{H}-\mathrm{eq})$ \\
\hline \multirow[t]{2}{*}{2} & $2.30(1 \mathrm{H}, \mathrm{ddd}, J=13.2,4.8,1.8 \mathrm{~Hz}, \mathrm{H}-\mathrm{ax})$ & $2.01(1 \mathrm{H}, \mathrm{dt}, J=12.0,2.4 \mathrm{~Hz}, \mathrm{H}-\mathrm{ax})$ & $1.99(1 \mathrm{H}, 1 \mathrm{H}, \mathrm{dt}, J=12.6,2.4 \mathrm{~Hz}, \mathrm{H}-\mathrm{ax})$ \\
\hline & $1.49(1 \mathrm{H}, \mathrm{m}, \mathrm{H}-\mathrm{eq})$ & $1.51(1 \mathrm{H}, \mathrm{m}, \mathrm{H}-\mathrm{eq})$ & $1.49(1 \mathrm{H}, \mathrm{m}, \mathrm{H}-\mathrm{eq})$ \\
\hline 3 & $3.56(1 \mathrm{H}, \mathrm{m})$ & $3.99(1 \mathrm{H}, \mathrm{m})$ & $4.09(1 \mathrm{H}, \mathrm{m})$ \\
\hline \multirow[t]{2}{*}{4} & $2.22(1 \mathrm{H}, \mathrm{td}, J=12.6,2.4 \mathrm{~Hz}, \mathrm{H}-\mathrm{ax})$ & $1.77(1 \mathrm{H}, \mathrm{br} \mathrm{d}, J=12.0 \mathrm{~Hz}, \mathrm{H}-\mathrm{ax})$ & $1.84(1 \mathrm{H}$, br d, $J=12.0 \mathrm{~Hz}, \mathrm{H}-\mathrm{ax})$ \\
\hline & $1.48(1 \mathrm{H}, \mathrm{d}, J=2.4 \mathrm{~Hz}, \mathrm{H}-\mathrm{eq})$ & $1.53(1 \mathrm{H}, \mathrm{m}, \mathrm{H}-\mathrm{eq})$ & $1.54(1 \mathrm{H}, \mathrm{m}, \mathrm{H}-\mathrm{eq})$ \\
\hline 5 & - & - & $1.61(1 \mathrm{H}, \mathrm{m})^{d}$ \\
\hline 6 & $5.34(1 \mathrm{H}, \mathrm{br} \mathrm{d}, J=4.8 \mathrm{~Hz})$ & $4.68(1 \mathrm{H}, \mathrm{t}, J=2.4 \mathrm{~Hz})$ & $4.70(1 \mathrm{H}, \mathrm{m})$ \\
\hline \multirow[t]{2}{*}{7} & $2.02(1 \mathrm{H}, \mathrm{dt}, J=12.6,4.8 \mathrm{~Hz}, \mathrm{H}-\mathrm{ax})$ & $1.68(1 \mathrm{H}, \mathrm{dd}, J=13.8,2.4 \mathrm{~Hz}, \mathrm{H}-\mathrm{ax})$ & $1.64(1 \mathrm{H}, \mathrm{m})$ \\
\hline & $1.96(1 \mathrm{H}, \mathrm{m}, \mathrm{H}-\mathrm{eq})$ & $1.47(1 \mathrm{H}, \mathrm{d}, J=2.4, \mathrm{H}-\mathrm{eq})$ & $1.61(1 \mathrm{H}, \mathrm{m})^{d}$ \\
\hline 8 & $1.52(1 \mathrm{H}, \mathrm{m})$ & $1.52(1 \mathrm{H}, \mathrm{m})$ & $1.29(1 \mathrm{H}, \mathrm{m})$ \\
\hline 9 & $1.16(1 \mathrm{H}, \mathrm{m})$ & $1.63(1 \mathrm{H}, \mathrm{m})$ & $1.68(1 \mathrm{H}, \mathrm{m})$ \\
\hline 10 & - & - & - \\
\hline \multirow[t]{2}{*}{11} & $1.43(1 \mathrm{H}, \mathrm{m})$ & $1.34(1 \mathrm{H}, \mathrm{m})$ & $1.73(1 \mathrm{H}, \mathrm{dd}, J=14.4,7.2 \mathrm{~Hz} \mathrm{H}-\mathrm{ax})$ \\
\hline & $1.32(1 \mathrm{H}, \mathrm{m})$ & $1.32(1 \mathrm{H}, \mathrm{m})$ & $0.77(1 \mathrm{H}, \mathrm{m}, \mathrm{H}-\mathrm{eq})$ \\
\hline
\end{tabular}


Table 1. Cont.

\begin{tabular}{|c|c|c|c|}
\hline \multirow[t]{2}{*}{12} & $1.28(1 \mathrm{H}, \mathrm{m})$ & $1.58(1 \mathrm{H}, \mathrm{m})$ & \multirow{2}{*}{$4.31(1 \mathrm{H}, \mathrm{td}, J=7.2,0.6 \mathrm{~Hz})$} \\
\hline & $0.97(1 \mathrm{H}, \mathrm{m})$ & $1.42(1 \mathrm{H}, \mathrm{m})$ & \\
\hline 13 & - & - & - \\
\hline 14 & $1.33(1 \mathrm{H}, \mathrm{m})$ & $1.25(1 \mathrm{H}, \mathrm{m})$ & $1.30(1 \mathrm{H}, \mathrm{m})$ \\
\hline 15 & $1.44(1 \mathrm{H}, \mathrm{m})$ & $1.55(1 \mathrm{H}, \mathrm{m})$ & $1.51(1 \mathrm{H}, \mathrm{m})$ \\
\hline \multirow{3}{*}{16} & $0.94(1 \mathrm{H}, \mathrm{m})$ & $1.03(1 \mathrm{H}, \mathrm{m})$ & $1.02(1 \mathrm{H}, \mathrm{m})$ \\
\hline & $1.88(1 \mathrm{H}, \mathrm{m})$ & $1.89(1 \mathrm{H}, \mathrm{m})$ & $1.86(1 \mathrm{H}, \mathrm{m})$ \\
\hline & $1.45(1 \mathrm{H}, \mathrm{m})$ & $1.50(1 \mathrm{H}, \mathrm{m})$ & $1.40(1 \mathrm{H}, \mathrm{m})$ \\
\hline 17 & $1.15(1 \mathrm{H}, \mathrm{m})$ & $1.05(1 \mathrm{H}, \mathrm{m})$ & $1.10(1 \mathrm{H}, \mathrm{m})$ \\
\hline 18 & $0.70(3 \mathrm{H}, \mathrm{s})$ & $0.78(3 \mathrm{H}, \mathrm{s})$ & $0.68(3 \mathrm{H}, \mathrm{s})$ \\
\hline 19 & $1.00(3 \mathrm{H}, \mathrm{s})$ & $1.14(3 \mathrm{H}, \mathrm{s})$ & $1.16(3 \mathrm{H}, \mathrm{s})$ \\
\hline 20 & $1.50(1 \mathrm{H}, \mathrm{m})$ & $1.36(1 \mathrm{H}, \mathrm{m})$ & $1.39(1 \mathrm{H}, \mathrm{m})$ \\
\hline 21 & $1.08(3 \mathrm{H}, \mathrm{d}, J=6.6 \mathrm{~Hz})$ & $0.94(3 \mathrm{H}, \mathrm{d}, J=6.6 \mathrm{~Hz})$ & $0.93(3 \mathrm{H}, \mathrm{d}, J=6.6 \mathrm{~Hz})$ \\
\hline 22 & $1.84(1 \mathrm{H}, \mathrm{m})$ & $1.62(1 \mathrm{H}, \mathrm{m})$ & $1.62(1 \mathrm{H}, \mathrm{m})$ \\
\hline \multirow{3}{*}{23} & $1.10(1 \mathrm{H}, \mathrm{m})$ & $1.01(1 \mathrm{H}, \mathrm{m})$ & $1.08(1 \mathrm{H}, \mathrm{m})$ \\
\hline & \multirow{2}{*}{$3.71(1 \mathrm{H}, \mathrm{ddd}, J=12.0,8.4,3.0 \mathrm{~Hz})$} & $1.68(1 \mathrm{H}, \mathrm{m})$ & $1.86(1 \mathrm{H}, \mathrm{m})$ \\
\hline & & $0.77(1 \mathrm{H}, \mathrm{m})$ & $0.78(1 \mathrm{H}, \mathrm{m})$ \\
\hline 24 & $1.56(1 \mathrm{H}, \mathrm{m})$ & $1.27(1 \mathrm{H}, \mathrm{m})$ & $1.28(1 \mathrm{H}, \mathrm{m})$ \\
\hline 25 & - & - & - \\
\hline 26 & $1.23(3 \mathrm{H}, \mathrm{s})^{c}$ & $1.09(3 \mathrm{H}, \mathrm{s})$ & $1.15(3 \mathrm{H}, \mathrm{s})^{e}$ \\
\hline 27 & $1.23(3 \mathrm{H}, \mathrm{s})^{c}$ & $1.10(3 \mathrm{H}, \mathrm{s})$ & $1.15(3 \mathrm{H}, \mathrm{s})^{e}$ \\
\hline 28 & $0.81(3 \mathrm{H}, \mathrm{d}, J=6.6 \mathrm{~Hz})$ & $0.87(3 \mathrm{H}, \mathrm{d}, J=7.2 \mathrm{~Hz})$ & $0.89(3 \mathrm{H}, \mathrm{d}, J=7.2 \mathrm{~Hz})$ \\
\hline OAc & - & $2.02\left(3 \mathrm{H}, \mathrm{s}, \mathrm{CH}_{3} \mathrm{CO}-\right)$ & $2.06\left(3 \mathrm{H}, \mathrm{s}, \mathrm{CH}_{3} \mathrm{CO}-\right)$ \\
\hline
\end{tabular}

${ }^{a}$ Spectra were measured in $\mathrm{CDCl}_{3}(600 \mathrm{MHz}) ;{ }^{b}$ Spectra were measured in $\mathrm{CD}_{3} \mathrm{OD}(600 \mathrm{MHz}) .{ }^{c, d, e}$ Overlapping signals.

Table 2. ${ }^{13} \mathrm{C}-\mathrm{NMR}$ data for compounds $\mathbf{1}-\mathbf{3}$.

\begin{tabular}{|c|c|c|c|}
\hline $\mathrm{C \#}$ & $1,{ }^{a} \delta_{\mathrm{C}}$, type & $2,{ }^{b} \delta_{\mathrm{C}}$, type & $3,{ }^{a} \delta_{\mathrm{C}}$, type \\
\hline 1 & 37.2, $\mathrm{CH}_{2}$ & $33.2, \mathrm{CH}_{2}$ & $34.9, \mathrm{CH}_{2}$ \\
\hline 2 & 24.3, $\mathrm{CH}_{2}$ & $22.2, \mathrm{CH}_{2}$ & $21.1, \mathrm{CH}_{2}$ \\
\hline 3 & 71.8, CH & $67.9, \mathrm{CH}$ & $67.3, \mathrm{CH}$ \\
\hline 4 & $42.3, \mathrm{CH}_{2}$ & $31.6, \mathrm{CH}_{2}$ & $28.2, \mathrm{CH}_{2}$ \\
\hline 5 & $140.8, \mathrm{C}$ & 75.5, C & $30.7, \mathrm{CH}$ \\
\hline 6 & 121.6, $\mathrm{CH}$ & 77.8, $\mathrm{CH}$ & 76.1, $\mathrm{CH}$ \\
\hline 7 & $31.7, \mathrm{CH}_{2}$ & $32.5, \mathrm{CH}_{2}$ & $31.4, \mathrm{CH}_{2}$ \\
\hline 8 & $31.9, \mathrm{CH}$ & $32.2, \mathrm{CH}$ & $31.9, \mathrm{CH}$ \\
\hline 9 & $50.1, \mathrm{CH}$ & $46.2, \mathrm{CH}$ & $45.2, \mathrm{CH}$ \\
\hline 10 & $36.5, \mathrm{C}$ & $39.6, \mathrm{C}$ & $38.5, \mathrm{C}$ \\
\hline 11 & 21.1, $\mathrm{CH}_{2}$ & 29.1, $\mathrm{CH}_{2}$ & $40.5, \mathrm{CH}_{2}$ \\
\hline 12 & $39.7, \mathrm{CH}_{2}$ & $41.0, \mathrm{CH}_{2}$ & 73.7, $\mathrm{CH}$ \\
\hline 13 & $42.5, \mathrm{C}$ & 43.9, C & 42.7, C \\
\hline 14 & $56.6, \mathrm{CH}$ & $57.3, \mathrm{CH}$ & $55.8, \mathrm{CH}$ \\
\hline 15 & 21.0, $\mathrm{CH}_{2}$ & $25.2, \mathrm{CH}_{2}$ & $24.1, \mathrm{CH}_{2}$ \\
\hline 16 & $28.5, \mathrm{CH}_{2}$ & $29.3, \mathrm{CH}_{2}$ & $29.7, \mathrm{CH}_{2}$ \\
\hline 17 & $57.3, \mathrm{CH}$ & $57.4, \mathrm{CH}$ & $55.9, \mathrm{CH}$ \\
\hline 18 & $11.8, \mathrm{CH}_{3}$ & $12.6, \mathrm{CH}_{3}$ & $12.2, \mathrm{CH}_{3}$ \\
\hline
\end{tabular}


Table 2. Cont.

\begin{tabular}{clll}
\hline 19 & $19.4, \mathrm{CH}_{3}$ & $17.1, \mathrm{CH}_{3}$ & $16.5, \mathrm{CH}_{3}$ \\
20 & $35.0, \mathrm{CH}$ & $37.8, \mathrm{CH}$ & $36.3, \mathrm{CH}$ \\
21 & $23.2, \mathrm{CH}_{3}$ & $15.3, \mathrm{CH}_{3}$ & $19.0, \mathrm{CH}_{3}$ \\
22 & $44.2, \mathrm{CH}_{2}$ & $36.3, \mathrm{CH}_{2}$ & $39.9, \mathrm{CH}_{2}$ \\
23 & $75.8, \mathrm{CH}$ & $29.1, \mathrm{CH}_{2}$ & $30.6, \mathrm{CH}_{2}$ \\
24 & $48.9, \mathrm{CH}$ & $46.4, \mathrm{CH}$ & $45.4, \mathrm{CH}$ \\
25 & $75.2, \mathrm{C}$ & $74.2, \mathrm{C}$ & $75.3, \mathrm{C}$ \\
26 & $30.7, \mathrm{CH}_{3}$ & $26.0, \mathrm{CH}_{3}$ & $26.2, \mathrm{CH}_{3}$ \\
27 & $30.7, \mathrm{CH}_{3}$ & $27.2, \mathrm{CH}_{3}$ & $27.2, \mathrm{CH}_{3}$ \\
28 & $14.1, \mathrm{CH}_{3}$ & $19.6, \mathrm{CH}_{3}$ & $14.8, \mathrm{CH}_{3}$ \\
$\mathrm{CH}_{3} \mathrm{CO}$ & - & $21.4, \mathrm{CH}_{3}$ & $21.4, \mathrm{CH}_{3}$ \\
$\mathrm{CH}_{3} \mathrm{CO}$ & - & $172.1, \mathrm{C}$ & $164.5, \mathrm{C}$ \\
\hline
\end{tabular}

${ }^{a}$ Spectra were measured in $\mathrm{CDCl}_{3}(150 \mathrm{MHz}) ;{ }^{b}$ Spectra were measured in $\mathrm{CD}_{3} \mathrm{OD}(150 \mathrm{MHz})$.

Figure 2. ${ }^{1} \mathrm{H}-{ }^{1} \mathrm{H} \operatorname{COSY}(-)$ and $\mathrm{HMBC}(\rightarrow)$ correlations for compounds $\mathbf{1}-\mathbf{3}$.

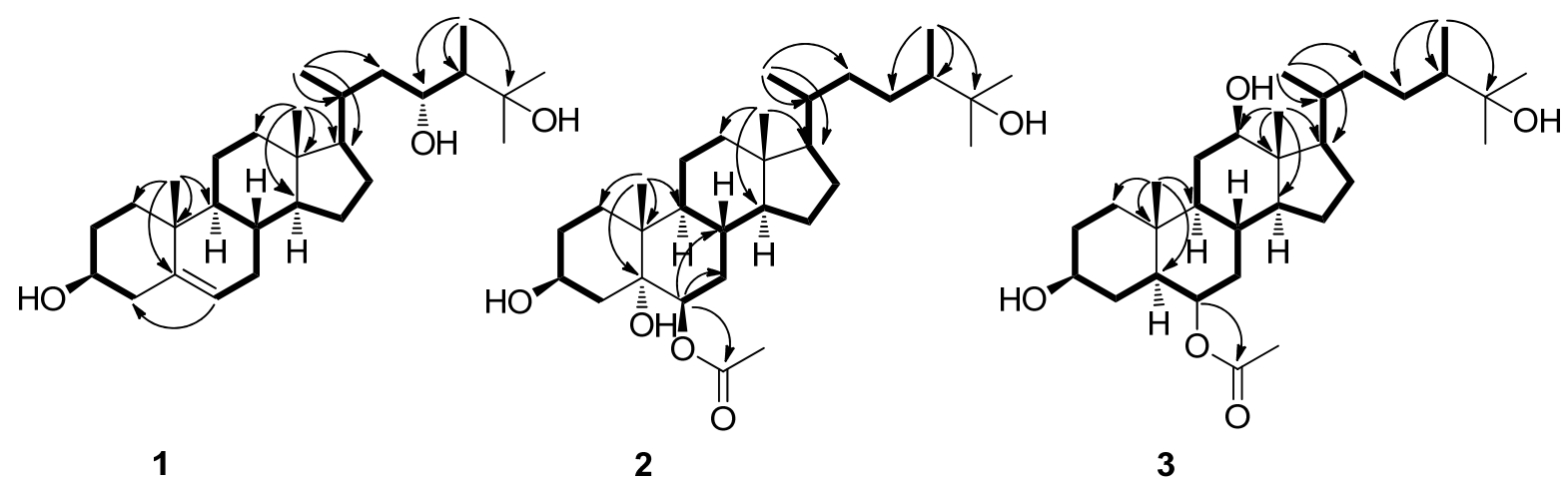

Figure 3. $\Delta \delta$ values $\left(\delta_{(S)}-\delta_{(R)}\right)$ for the MTPA esters of compound 1.

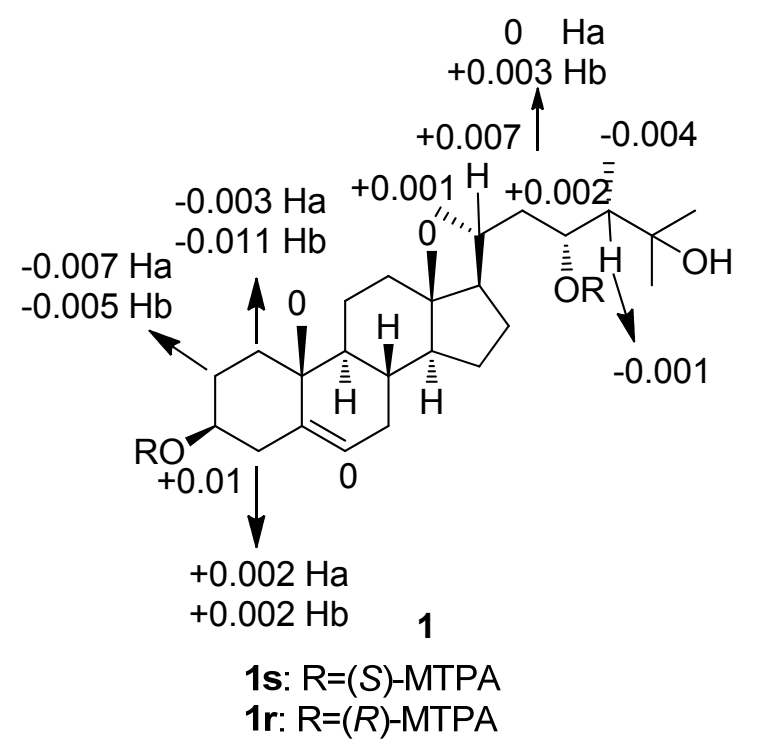

Compound 2 was obtained as a white, amorphous powder with $[\alpha]_{\mathrm{D}}{ }^{25}-45.6\left(c 0.90, \mathrm{CH}_{3} \mathrm{OH}\right)$. Its positive ion HRESIMS revealed a pseudo molecular ion peak at $\mathrm{m} / z 515.3711[\mathrm{M}+\mathrm{Na}]^{+}$(calcd for $\mathrm{C}_{30} \mathrm{H}_{52} \mathrm{O}_{5} \mathrm{Na}$ 515.3712), corresponding to the molecular formula $\mathrm{C}_{30} \mathrm{H}_{52} \mathrm{O}_{5}$, possessing five degrees of 
unsaturation. IR spectrum showed its absorption at $3234-3587 \mathrm{~cm}^{-1}$ for hydroxyl groups, and $1652 \mathrm{~cm}^{-1}$ for carbonyl (acetate) group. Comparison of the ${ }^{1} \mathrm{H}-\mathrm{NMR}$ (Table 1) and ${ }^{13} \mathrm{C}-\mathrm{NMR}$ (Table 2) data of 2 with those of the known compound 4 [17], revealed that 2 shares the same structure nucleus as $\mathbf{4}$, differing from 4 only at the side chain where the C-25 was oxygenated, in agreement with the mass data. The oxygenation of the C-25 caused the ${ }^{13} \mathrm{C}-\mathrm{NMR}$ resonance of C-26 and C-27 to be shifted significantly downfield (from $\delta_{\mathrm{C}} 21.5 / 21.6$ to 26.0/27.2) and two singlet methyl signals appeared in 2 $\left[\delta_{\mathrm{H}} 1.09(3 \mathrm{H}, \mathrm{s}), 1.10(3 \mathrm{H}, \mathrm{s})\right]$ instead of two doublet methyls in $4\left[\delta_{\mathrm{H}} 0.77(3 \mathrm{H}, \mathrm{d}, J=6.6 \mathrm{~Hz}), 0.78\right.$ $(3 \mathrm{H}, \mathrm{d}, J=6.6 \mathrm{~Hz})]$ in the ${ }^{1} \mathrm{H}-\mathrm{NMR}$ spectrum. According to these data, compound 2 was assigned as the 25-OH derivative of 4 . In addition, the HMBC (Figure 2) correlation from H-6 to ester carbonyl carbon at $\delta_{\mathrm{C}} 172.1\left(\mathrm{CH}_{3} \mathrm{CO}\right)$, suggesting that the acetoxy group was positioned at $\mathrm{C}-6$. The assigned relative configuration at C-6 was confirmed by that $\mathrm{H}-6\left(\delta_{\mathrm{H}} 4.68(1 \mathrm{H}, \mathrm{t}, J=2.4 \mathrm{~Hz})\right)$ was coupled with $\mathrm{H}-7 \alpha$ (equatorial) $\left(\delta_{\mathrm{H}} 1.47\right)$ with a small coupling constant of $2.4 \mathrm{~Hz}$. Consequently, $\mathrm{H}-6$ was in equatorial orientation, indicating the location of the acetoxy group was at axial position. Furthermore, the NOE cross-peaks observed between $\mathrm{H}_{3}-19\left(\delta_{\mathrm{H}} 1.14\right)$ and both $\mathrm{H}-4 \beta\left(\delta_{\mathrm{H}} 1.77\right)$ and $\mathrm{H}-2 \beta\left(\delta_{\mathrm{H}} 2.01\right)$, and the absence of NOE correlations between $\mathrm{H}_{3}-19$ and both H-3 and H-6 implied that H-3 and H-6 are both $\alpha$ oriented. At the same time the NOE correlations observed between H- $4 \alpha$ and both H-3 and H-6 further confirmed that H-3 and H-6 were $\alpha$ oriented. The configuration of the side chain of 2 was also confirmed by NOE correlations from $\mathrm{H}_{3}-18$ to $\mathrm{H}-20$. So the structure of compound 2 was determined as $(24 S)$-ergostane-6-acetate-3 $\beta, 5 \alpha, 6 \beta, 25$-tetraol.

Compound 3 was obtained as a white, amorphous powder with $[\alpha]_{\mathrm{D}}{ }^{25}-26.6\left(c 0.50, \mathrm{CH}_{3} \mathrm{OH}\right)$. It was found to have the same molecular formula $\left(\mathrm{C}_{30} \mathrm{H}_{52} \mathrm{O}_{5}\right)$ as $\mathbf{2}$, as determined from high-resolution mass measurements which revealed a pseudo molecular ion peak at $\mathrm{m} / z 515.3710[\mathrm{M}+\mathrm{Na}]^{+}$, (calcd for $\mathrm{C}_{30} \mathrm{H}_{52} \mathrm{O}_{5} \mathrm{Na}$ 515.3712). Both compounds (2 and 3) showed similarity in the ${ }^{1} \mathrm{H}$ NMR and ${ }^{13} \mathrm{C}$ NMR spectra (Tables 1 and 2), with the most significant difference being the chemical shifts of $\mathrm{C}-5\left(\delta_{\mathrm{C}} 75.5, \mathrm{C}\right.$ in 2 vs. $\delta_{\mathrm{C}} 30.7, \mathrm{CH}$ in 3$)$ and $\mathrm{C}-12\left(\delta_{\mathrm{C}} 41.0, \mathrm{CH}_{2}\right.$ in 2 vs. $\delta_{\mathrm{C}} 73.7, \mathrm{CH}$ in 3$)$. This indicated that the location of a hydroxyl group in $\mathbf{3}$ was different from that of in $\mathbf{2}$. The established planar structure of $\mathbf{3}$ was further supported by the 2D NMR spectra. The diagnostic HMBC correlation from $\mathrm{H}_{3}-18$ to $\mathrm{C}-12$ and ${ }^{1} \mathrm{H}-{ }^{1} \mathrm{H}$ COSY correlations between $\mathrm{H}-12$ and $\mathrm{H}-11$ (Figure 2) led the location of the hydroxyl group at $\mathrm{C}-12$. The relative configuration of $\mathrm{C}-12$ was established by comparison with the known compound $\mathbf{8}$ ( $3 \alpha$-acetoxy-12 $\alpha$-hydroxy-5 $\beta$-cholan-24-oic acid). The small coupling constant of $\mathrm{H}-12\left(\delta_{\mathrm{H}} 3.99,1 \mathrm{H}, \mathrm{t}, J=2.6 \mathrm{~Hz}\right)$ in 8 means that $\mathrm{H}-12$ is at equatorial position according to the literature [23]. Whereas the large coupling constant of $\mathrm{H}-12\left(\delta_{\mathrm{H}} 4.31,1 \mathrm{H}, \mathrm{td}, J=7.2,0.6 \mathrm{~Hz}\right)$ in 3 supported the axial position of H-12. Moreover, NOE correlations observed from both $\mathrm{H}-14$ and H-9 to $\mathrm{H}-12$ and the absence of NOE correlations between $\mathrm{H}_{3}-18$ and $\mathrm{H}-12$ also implied $\mathrm{H}-12$ was at $\alpha$ orientation. The chemical shift of $\mathrm{H}-3\left(\delta_{\mathrm{H}} 4.09\right)$ suggested that $3-\mathrm{OH}$ was $\beta$ oriented and $\mathrm{H}-5$ was $\alpha$ oriented by comparison with the ${ }^{1} \mathrm{H}-\mathrm{NMR}$ data of $3 \beta$-hydroxy-5 $\alpha$-oxygenated A/B trans sterols [24,25]. Based on the above analysis, the relative configuration of $\mathbf{3}$ was assigned, and the structure was elucidated as (24S)-ergostane-6-acetate-3 $\beta, 6 \beta, 12 \beta, 25$-tetraol.

The structures of compounds 4, 5 and $\mathbf{6}$ were identified as $24(S)$-methylcholestane-3 $\beta, 5 \alpha, 6 \beta$-triol-6monoacetate [17], 24-methylenecholestane-3 $\beta, 5 \alpha, 6 \beta$-triol-6-monoacetate [17], and ergost-24(28)-en$3 \beta, 5 \alpha, 6 \beta$-triol [18], respectively, by comparison of their spectroscopic data with those in the literature. 
All the isolated compounds (1-6) were evaluated for their cytotoxic activity against a panel of five human tumor cell lines (Hela, HL-60, K562, A-549 and SMMC-7721) and lethality toward brine shrimp A. salina. Only compound 5 exhibited moderate cytotoxicity against K562 cell line with an $\mathrm{IC}_{50}$ value of $3.18 \mu \mathrm{M}$. Moreover, compound 5 also displayed strong lethality toward brine shrimp A. salina with a $\mathrm{LC}_{50}$ value of $0.96 \mu \mathrm{M}$. For the other compounds, no cytotoxic activity at the concentration of $10 \mu \mathrm{M}$ and no lethality toward brine shrimp at $25 \mu \mathrm{g} / \mathrm{mL}$ were found.

\section{Experimental Section}

\subsection{General Experimental Procedures}

Optical rotations were measured in methanol using a JASCO P-1020 digital polarimeter. UV spectra were recorded on a Beckman DU 640 spectrophotometer. IR spectra were measured on a Bruker VECTOR 22 spectrophotometer. ${ }^{1} \mathrm{H}$ - and ${ }^{13} \mathrm{C}-\mathrm{NMR}$ spectra were recorded on a JEOL Eclips-600 spectrometer. ESIMS and HRESIMS were measured on a Q-TOF Ultima Global GAA076 LC mass spectrometer. Silica gel (Qing Dao Hai Yang Chemical Group Co.; 200-300 and 300-400 mesh), octadecylsilyl silica gel (Unicorn; 45-60 $\mu \mathrm{m}$ ) and Sephadex LH-20 (Amersham Biosciences) were used for column chromatography (CC). Precoated silica gel plates (Yan Tai Zi Fu Chemical Group Co.; G60, F-254) were used for thin layer chromatography (TLC). Semi-preparative HPLC was performed on a Waters 1525 system using a semi-preparative C18 (Kromasil $7 \mu \mathrm{m}, 10 \times 250 \mathrm{~mm}$ ) column coupled with a Waters 2996 photodiode array detector.

\subsection{Animal Materials}

Soft coral Sinularia sp. was collected from the coral reef of Weizhou Island in the South China Sea in September 2008, and was identified by Prof. Hui Huang, South China Sea Institute of Oceanology, Chinese Academy of Sciences of China. The voucher specimen (No. GX-WZ-2008002-4) was deposited in the Key Laboratory of Marine Drugs, the Ministry of Education, Ocean University of China, Qingdao, China.

\subsection{Extraction and Isolation}

The frozen animals (dry weight $559.7 \mathrm{~g}$ ) were cut into small pieces and exhaustively extracted with EtOH once $(3000 \mathrm{~mL})$ and $\mathrm{CHCl}_{3}-\mathrm{CH}_{3} \mathrm{OH}(1: 1)$ for six times $(3000 \mathrm{~mL} \times 6)$ successively at room temperature. The organic extracts were evaporated to give a residue, which was suspended into $\mathrm{H}_{2} \mathrm{O}$ and partitioned with ethyl acetate. The ethyl acetate fraction was concentrated under reduced pressure to give a residue $(28.0 \mathrm{~g})$, which was subjected to gradient silica gel chromatography, eluting with 0\%-100\% ethyl acetate in light petroleum ether and $20 \%-100 \% \mathrm{CH}_{3} \mathrm{OH}$ in $\mathrm{CHCl}_{3}$ to afford nine fractions (Fr. 1-Fr. 9). Fr. 6 was fractionated on silica gel column chromatography eluting with petroleum ether-ethyl acetate (5:1-1:2), and then chromatographed on Sephadex LH-20 eluted with petroleum ether- $\mathrm{CHCl}_{3}-\mathrm{MeOH} \quad(2: 1: 1)$ to give Fr.61. Further purification of Fr. 61 by semi-preparative HPLC yielded compound 4 ( $8.4 \mathrm{mg})$. Fr. 7 and Fr. 8 were firstly isolated by repeated silica gel chromatography, further purified by Sephadex LH-20 $\left(\mathrm{CHCl}_{3}-\mathrm{MeOH}\right.$ 1:1) and reversed-phase silica gel chromatography, and finally subjected to RP-HPLC to yield 5 (27.8 mg) and 6 (22.9 mg), 
respectively. Fr. 9 was chromatographed on silica gel eluting with petroleum ether-EtOAc (1:3), and further purified by RP-HPLC $\left(\mathrm{MeOH} / \mathrm{H}_{2} \mathrm{O} 90: 10\right.$, flow rate of $\left.2.0 \mathrm{~mL} / \mathrm{min}\right)$ to afford $1(1.8 \mathrm{mg}$, $\left.t_{\mathrm{R}}=26.5 \mathrm{~min}\right), 2\left(11.3 \mathrm{mg}, t_{\mathrm{R}}=27.5 \mathrm{~min}\right)$, and $\mathbf{3}\left(1.3 \mathrm{mg}, t_{\mathrm{R}}=32.7 \mathrm{~min}\right)$ successively.

Compound (1): White amorphous powder; $[\alpha]_{\mathrm{D}}{ }^{25}-22.4$ (c $\left.0.05, \mathrm{CH}_{3} \mathrm{OH}\right)$; IR (KBr) $v_{\max }$ 3410-3584 $\mathrm{cm}^{-1}$; UV (MeOH) $\lambda_{\max }: 198 \mathrm{~nm},{ }^{1} \mathrm{H} \mathrm{NMR}\left(\mathrm{CDCl}_{3}, 600 \mathrm{MHz}\right)$ and ${ }^{13} \mathrm{C} \mathrm{NMR}\left(\mathrm{CDCl}_{3}\right.$, $150 \mathrm{MHz}$ ) data in Tables 1 and 2; HRESIMS $m / z$ 455.3498 [M + Na] $]^{+}$(calcd for $\mathrm{C}_{28} \mathrm{H}_{48} \mathrm{O}_{3} \mathrm{Na}, 455.3496$ ).

Compound (2): White amorphous powder; $[\alpha]_{\mathrm{D}}^{25}-45.6$ (c $\left.0.90, \mathrm{CH}_{3} \mathrm{OH}\right)$; IR $(\mathrm{KBr}) v_{\max }$ at 3234-3587, $1652 \mathrm{~cm}^{-1}$; UV $(\mathrm{MeOH}) \lambda_{\max }: 195 \mathrm{~nm},{ }^{1} \mathrm{H}$ NMR $\left(\mathrm{CD}_{3} \mathrm{OD}, 600 \mathrm{MHz}\right)$ and ${ }^{13} \mathrm{C} \mathrm{NMR}$ $\left(\mathrm{CD}_{3} \mathrm{OD}, 150 \mathrm{MHz}\right)$ data in Tables 1 and 2; HRESIMS $\mathrm{m} / z$ 515.3711 $[\mathrm{M}+\mathrm{Na}]^{+}$(calcd for $\mathrm{C}_{30} \mathrm{H}_{52} \mathrm{O}_{5} \mathrm{Na}, 515.3712$ ).

Compound (3): White amorphous powder; $[\alpha]_{\mathrm{D}}^{25}-26.6\left(c 0.50, \mathrm{CH}_{3} \mathrm{OH}\right)$; IR $(\mathrm{KBr}) v_{\max } 3434$, 3214, $1638 \mathrm{~cm}^{-1}$; UV (MeOH) $\lambda_{\max }: 197 \mathrm{~nm},{ }^{1} \mathrm{H} \mathrm{NMR}\left(\mathrm{CDCl}_{3}, 600 \mathrm{MHz}\right)$ and ${ }^{13} \mathrm{C} \mathrm{NMR}\left(\mathrm{CDCl}_{3}\right.$, $150 \mathrm{MHz}$ ) data in Tables 1 and 2; HRESIMS $m / z$ 515.3710 $[\mathrm{M}+\mathrm{Na}]^{+}$(calcd for $\mathrm{C}_{30} \mathrm{H}_{52} \mathrm{O}_{5} \mathrm{Na}, 515.3712$ ).

\subsection{Preparation of the (S)-and (R)-MTPA Esters of 1}

Compound $1(0.5 \mathrm{mg})$ was dissolved in $500 \mu \mathrm{L}$ of pyridine, and dimethylaminopyridine $(2.0 \mathrm{mg})$ and $(R)$-MTPACl $(10 \mu \mathrm{L})$ were then added in sequence. The reaction mixture was stirred for $24 \mathrm{~h}$ at room temperature, and $1 \mathrm{~mL}$ of $\mathrm{H}_{2} \mathrm{O}$ was then added. The solution was extracted with $5 \mathrm{~mL}$ of $\mathrm{CH}_{2} \mathrm{Cl}_{2}$ and the organic phase was concentrated under reduced pressure. Then the residue was purified by semi-preparative HPLC $(100 \% \mathrm{MeOH})$ to yield $(S)$-MTPA ester $1 \mathrm{~s}\left(0.3 \mathrm{mg}, t_{\mathrm{R}}=23.40 \mathrm{~min}\right)$. By the same procedure, the $(R)$-MTPA ester $1 \mathbf{r}\left(0.3 \mathrm{mg}, t_{\mathrm{R}}=26.21 \mathrm{~min}\right)$ was obtained from the reaction of 1 $(0.5 \mathrm{mg})$ with $(S)$-MTPACl $(10 \mu \mathrm{L})$. Selected ${ }^{1} \mathrm{H} \mathrm{NMR}\left(\mathrm{CDCl}_{3}, 600 \mathrm{MHz}\right)$ of $(S)$-MTPA ester $(\mathbf{1 s})$ : $\delta$ 7.08-7.43 (5H, Ph), 5.348 (1H, m, H-23), 5.30 (1H, s, H-6), 5.17 (1H, m, H-3), 2.769 (1H, m, H-2a), 2.766 (1H, m, H-4a), 2.046 (1H, m, H-1a), 2.045 (1H, m, H-20), 2.01 (1H, m, H-22), 1.994 (1H, m, $\mathrm{H}-2 \mathrm{~b}), 1.986$ (1H, m, H-4b), 1.350 (1H, m, H-1b), 1.314 (1H, m, H-22), 1.269 (1H, m, H-24), $1.25\left(6 \mathrm{H}, \mathrm{s}, \mathrm{H}_{3}-26\right.$ and $\left.\mathrm{H}_{3}-27\right), 0.994\left(3 \mathrm{H}, \mathrm{d}, J=6.6 \mathrm{~Hz}, \mathrm{H}_{3}-21\right), 0.99$ (3H, s, $\left.\mathrm{H}_{3}-19\right), 0.879$ (3H, d, $\left.J=6.0 \mathrm{~Hz}, \mathrm{H}_{3}-28\right), 0.87\left(3 \mathrm{H}, \mathrm{s}, \mathrm{H}_{3}-18\right)$; selected ${ }^{1} \mathrm{H}$ NMR $\left(\mathrm{CDCl}_{3}, 600 \mathrm{MHz}\right)$ of $(R)$-MTPA ester (1r): $\delta$ 7.08-7.43 (5H, Ph), 5.346 (1H, m, H-23), 5.30 (1H, s, H-6), 5.16 (1H, m, H-3), 2.776 (1H, m, H-2a), 2.764 (1H, m, H-4a), 2.049 (1H, m, H-1a), 2.038 (1H, m, H-20), 2.01 (1H, m, H-22), 1.999 (1H, m, $\mathrm{H}-2 \mathrm{~b}), 1.984$ (1H, m, H-4b), 1.361 (1H, m, H-1b), 1.311 (1H, m, H-22), 1.270 (1H, m, H-24), $1.25\left(6 \mathrm{H}, \mathrm{s}, \mathrm{H}_{3}-26\right.$ and $\left.\mathrm{H}_{3}-27\right), 0.993\left(3 \mathrm{H}, \mathrm{d}, J=6.6 \mathrm{~Hz}, \mathrm{H}_{3}-21\right), 0.99$ (3H, s, $\left.\mathrm{H}_{3}-19\right), 0.883(3 \mathrm{H}, \mathrm{d}$, $\left.J=6.0 \mathrm{~Hz}, \mathrm{H}_{3}-28\right), 0.87\left(3 \mathrm{H}, \mathrm{s}, \mathrm{H}_{3}-18\right)$.

\subsection{Cytotoxicity Assay}

The cytotoxicity against Hela (cervical cancer cells), HL-60 (Human promyelocytic leukemia cells), A-549 (human lung epithelial carcinoma), SMMC-7721 (human hepatocellular carcinoma cell line), and K562 (human immortalised myelogenous leukemia line) cell lines were evaluated by using SRB [26] and MTT [27] methods, respectively, according to the protocols described in previous literature. The test of brine shrimp toxicity on A. salina was performed according to standard protocols [28,29]. 


\section{Conclusions}

In our continuing discovery for biological secondary metabolites from marine invertebrates in the South China Sea, this study provided a series of polyoxygenated sterols. The discovery of new compounds 1-3 has added to an extremely diverse and complex array of soft coral sterols. Further studies should be conducted to unambiguously establish their absolute configurations by total synthesis as well as to understand their biological/ecological roles in the life cycle of the animal.

\section{Acknowledgements}

This work was supported by the Key Program of National Natural Science Foundation of China (No. 41130858), the National Natural Science Foundation of China (Nos. 40976077; 30901879; 41176121; 81172977), Program for New Century Excellent Talents in University, Ministry of Education of China (No. NCET- 11-0472), the Research Fund for the Doctoral Program of Higher Education, Ministry of Education of China (No. 20090132110002), and the Program for Changjiang Scholars and Innovative Research Team in University, Ministry of Education of China (No. IRT0944).

\section{References}

1. Blunt, J.W.; Copp, B.R.; Munro, M.H.G.; Northcote, P.T.; Prinsep, M.R. Marine natural products. Nat. Prod. Rep. 2006, 23, 26-78.

2. Chao, C.H.; Hsieh, C.H.; Chen, S.P.; Lu, C.K.; Dai, C.F.; Sheu, J.H. Sinularianins A and B, novel sesquiterpenoids from the Formosan soft coral Sinularia sp. Tetrahedron Lett. 2006, 47, 5889-5891.

3. Choi, Y.H.; Schmitz, F.J. Cytotoxic acylated spermidine from a soft coral, Sinularia sp. J. Nat. Prod. 1997, 60, 495-496.

4. Ojika, M.; Islam, M.K.; Shintani, T.; Zhang, Y.; Okamoto, T.; Sakagami, Y. Three new cytotoxic acylspermidines from the soft coral, Sinularia sp. Biosci. Biotechnol. Biochem. 2003, 67, 1410-1412.

5. Imbs, A.B.; Yakovleva, I.M.; Pham, L.Q. Distribution of lipids and fatty acids in the zooxanthellae and host of the soft coral Sinularia sp. Fish. Sci. 2010, 76, 375-380.

6. Chao, C.H.; Hsieh, C.H.; Chen, S.P.; Lu, C.K.; Dai, C.F.; Wu, Y.C.; Sheu, J.H. Novel cyclic sesquiterpene peroxides from the Formosan soft coral Sinularia sp. Tetrahedron Lett. 2006, 47, 2175-2178.

7. Sheu, J.H.; Chang, K.C.; Duh, C.Y. A cytotoxic 5 $\alpha, 8 \alpha$-epidioxysterol from a soft coral Sinularia species. J. Nat. Prod. 2000, 63, 149-151.

8. Jia, R.; Guo, Y.W.; Mollo, E.; Gavagnin, M.; Cimino, G. Two new polyhydroxylated steroids from the Hainan soft coral Sinularia sp. Helv. Chim. Acta 2006, 89, 1330-1336.

9. Takaki, H.; Koganemaru, R.; Iwakawa, Y.; Higuchi, R.; Miyamoto, T. Inhibitory effect of norditerpenes on LPS-induced TNF- $\alpha$ production from the Okinawan soft coral, Sinularia sp. Biol. Pharm. Bull. 2003, 26, 380-382.

10. Shoji, N.; Umeyama, A.; Arihara, S. A novel norditerpenoid from the Okinawan soft coral Sinularia sp. J. Nat. Prod. 1993, 56, 1651-1653. 
11. Wang, C.Y.; Chen, A.N.; Shao, C.L.; Li, L.; Xu, Y.; Qian, P.Y. Chemical constituents of soft coral Sarcophyton infundibuliforme from the South China Sea. Biochem. Syst. Ecol. 2011, 39, 853-856.

12. Han, L.; Wang, C.Y.; Huang, H.; Shao, C.L.; Liu, Q.A.; Qi, J.; Sun, X.P.; Zhai, P.; Gu, Y.C. A new pregnane analogue from Hainan soft coral Scleronephthya gracillimum Kuekenthal. Biochem. Syst. Ecol. 2010, 38, 243-246.

13. Li, L.; Sheng, L.; Wang, C.Y.; Zhou, Y.B.; Huang, H.; Li, X.B.; Li, J.; Mollo, E.; Gavagnin, M.; Guo, Y.W. Diterpenes from the Hainan soft coral Lobophytum cristatum Tixier-Durivault. J. Nat. Prod. 2011, 74, 2089-2094.

14. Sun, X.P.; Wang, C.Y.; Shao, C.L.; Li, L.; Li, X.B.; Chen, M.; Qian, P.Y. Chemical constituents of the soft coral Sarcophyton infundibuliforme from the South China Sea. Nat. Prod. Commun. 2010, $5,1171-1174$.

15. Li, L.; Wang, C.Y.; Shao, C.L.; Guo, Y.W.; Li, G.Q.; Sun, X.P.; Han, L.; Huang, H.; Guan, H.S. Sarcoglycosides A-C, new $O$-glycosylglycerol derivatives from the South China Sea soft coral Sarcophyton infundibuliforme. Helv. Chim. Acta 2009, 92, 1495-1502.

16. Li, L.; Wang, C.Y.; Shao, C.L.; Han, L.; Sun, X.P.; Zhao, J.; Guo, Y.W.; Huang, H.; Guan, H.S. Two new metabolites from the Hainan soft coral Sarcophyton crassocaule. J. Asian Nat. Prod. Res. 2009, 11, 851-855.

17. Bortolotto, M.; Braekman, J.C.; Daloze, D.; Tursch, B. Chemical studies of marine invertebrates. XVIII. Four novel polyhydroxylated steroids from Sinularia dissecta (Coelenterata, Octocorallia, Alcyonacea). Bull. Soc. Chim. Belges 1976, 85, 27-34.

18. Lan, W.J.; Su, J.Y.; Zeng, L.M. Studies on the secondary metabolites of the soft coral, Sinularia sp. collected from the South China Sea. Acta Sci. Nat. Univ. Sunyatseni 2003, 42, 105-107.

19. Yeffet, D.; Rudi, A.; Ketzinel, S.; Benayahu, Y.; Kashman, Y. Auroside, a xylosyl-sterol, and patusterol A and B, two hydroxylated sterols, from two soft corals Eleutherobia aurea and Lobophytum patulum. Nat. Prod. Commun. 2010, 5, 205-210.

20. Kusumi, T.; Fujita, Y.; Ohtani, I.; Kakisawa, H. Anomaly in the modified Mosher's method: Absolute configurations of some marine cembranolides. Tetrahedron Lett. 1991, 32, 2923-2926.

21. Kobayashi, M.; Hayashi, T.; Hayashi, K.; Tanabe, M.; Nakagawa, T.; Mitsuhashi, H. Marine sterols. XI. Polyhydroxysterols of the soft coral Sarcophyton glaucum: Isolation and synthesis of 5-cholestane-1 $\alpha, 3 \beta, 5,6 \beta$-tetrol. Chem. Pharm. Bull. 1983, 31, 1848-1855.

22. Al-Lihaibi, S.S.; Ayyad, S.N.; Shaher, F.; Alarif, W.M. Antibacterial sphingolipid and steroids from the black coral Antipathes dichotoma. Chem. Pharm. Bull. 2010, 58, 1635-1638.

23. Segura, M.; Alcfizar, V.; Prados, P.; Mendoza, J.D. Synthetic receptors for uronic acid salts based on bicyclic guanidinium and deoxycholic acid subunits. Tetrahedron 1999, 53, 13119-13128.

24. Yaoita, Y.; Amemiya, K.; Ohnuma, H.; Furumura, K.; Masaki, A.; Matsuki, T.; Kikuchi, M. Sterol constituents from five edible mushrooms. Chem. Pharm. Bull. 1998, 46, 944-950.

25. Ishizuka, T.; Yaoita, Y.; Kikuchi, M. Sterol constituents from the fruit bodies of Grifola frondosa (Fr.) S. F. Gray. Chem. Pharm. Bull. 1997, 45, 1756-1760.

26. Skehan, P.; Storeng, R.; Scudiero, D.; Monks, A.; McMahon, J.; Vistica, D.; Warren, J.T.; Bokesch, H.; Kenney, S.; Boyd, M.R. New colorimetric cytotoxicity assay for anticancer-drug screening. J. Natl. Cancer Inst. 1990, 82, 1107-1112. 
27. Mosmann, T. Rapid colorimetric assay for cellular growth and survival: Application to proliferation and cytotoxicity assays. J. Immunol. Methods 1983, 65, 55-63.

28. Solis, P.N.; Wright, C.W.; Anderson, M.M.; Gupta, M.P.; Phillipson, J.D. A microwell cytotoxicity assay using Artemia salina (brine shrimp). Planta Med. 1993, 59, 250-252.

29. Meyer, B.N.; Ferrigni, N.R.; Putnam, J.E.; Jacobson, L.B.; Nicols, D.E.; Mclaughlin, J.L. Brine shrimp: A convenient general bioassay for active plant constituents. Planta Med. 1982, 45, 31-34.

Samples Availability: Available from the authors.

(C) 2012 by the authors; licensee MDPI, Basel, Switzerland. This article is an open access article distributed under the terms and conditions of the Creative Commons Attribution license (http://creativecommons.org/licenses/by/3.0/). 